\title{
Meningkatkan Hasil Belajar Siswa Melalui Media Microsoft PowerPoint di SMKN 1 Tunjung Teja
}

\author{
Author: \\ Anton Sulistyono ${ }^{1}$ \\ Supardi U.S ${ }^{2}$ \\ Afiliation: \\ Universitas Indraprasta \\ $\mathrm{PGRI}^{1,2}$ \\ Corresponding email \\ anton030258@gmail.com \\ Histori Naskah: \\ Submit: 2021-11-18 \\ Accepted: 2021-11-19 \\ Published: 2021-12-01

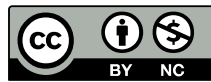

\begin{abstract}
Abstrak:
Penelitian ini bertujuan untuk mengukur besarnya peningkatan hasil belajar siswa melalui media Microsoft Powerpoint pada mata pelajaran dasar perancangan teknik mesin di Kelas X TMI 2 di SMKN 1 Tunjung Teja Kabupaten Serang Semester 1 Tahun Pelajaran 2020/2021. Metode penelitian ini adalah kualitatif dengan sampel sejumlah 20 siswa kelas X TMI 2 di SMKN 1 Tunjung Teja Kabupaten Serang. Hasil dan kesimpulan dari penelitian ini adalah hasil belajar dengan melihat presentase daya serap klasikal dan ketuntasan bealajar klasikal yang mengalami peningkatan pada mata pelajaran dasar perancangan teknik mesin di Kelas X TMI 2 di SMKN 1 Tunjung Teja Kabupaten Serang. Pada saat pembelajaran diubah menggunakan media Microsoft powerpoint, hasil tes tindakan siklus I diperoleh siswa yang tuntas 6 orang dan tidak tuntas 14 orang siswa dengan persentase daya serap klasikal sebesar $47 \%$ dan ketuntasan belajar klasikal mencapai $30 \%$. Pada siklus II hasil tes tindakan, siswa yang tuntas 13 orang dan 7 orang siswa tidak tuntas dengan persentase daya serap klasikal sebesar 76\% dan ketuntasan belajar klasikal sebesar 65\%. Pada akhir siklus III hasil tes tindakan, siswa yang tuntas 16 orang dan 4 orang siswa tidak tuntas dengan persentase daya serap klasikal sebesar $82 \%$ dan ketuntasan belajar klasikal sebesar $80 \%$.
\end{abstract} \\ Kata kunci: Hasil Belajar, Media Pembelajaran

\section{Pendahuluan} \\ Mata Pelajaran Dasar Perancangan Teknik Mesin merupakan salah satu mata pelajaran yang dianggap \\ sulit oleh sebagian besar siswa Teknik Pemeliharaan Mekanik Industri. Berdasarkan pengalaman dan \\ pengamatan mengajar di kelas, maka didapatkan siswa di kelas yang diajar tidak mendapat pemahaman \\ dan pengajaran yang cukup, semua itu dikarenakan kurangnya sumber belajar dan kurangnya suatu \\ platform yang menyediakan berbagai sumber belajar dan media pembelajaran. \\ Kecendrung pasif dalam kegiatan pembelajaran ini mengakibat hasil penguasaan konsep pembelajaran \\ yang dicapai menjadi rendah, hanya berkisar 11,11\% saja siswa dikatakan memenuhi Kriteria Kelulusan \\ Minimal (KKM). Kondisi ini terlihat dari banyaknya siswa yang kurang pemahaman dan pengaplikasian \\ konsep pembelajaran yang telah didapatkan. Hal tersebut terlihat dari nilai Ulangan Harian (UH) siswa \\ yang dilakukan oleh peneliti di kelas X TMI 2 pada Kompetensi Dasar (KD) Memahami persyaratan \\ perlakuan panas logam pada Tabel 1.1.
}

Tabel 1.1 Nilai Ulangan Harian (UH) 
Edu Cendikia: Jurnal Ilmiah Kependidikan

Volume: 1 | Nomor 3 | Desember 2021 | E-ISSN: 2798-365X | DOI: 10.47709/educendikia.v1i3.1178

\begin{tabular}{|c|c|c|c|}
\hline No & Nilai & Frekuensi & Prosentase (\%) \\
\hline 1 & $91-100$ & 0 & $0 \%$ \\
\hline 2 & $81-90$ & 0 & $0 \%$ \\
\hline 3 & $71-80$ & 4 & $11.11 \%$ \\
\hline 4 & $0-70$ & 32 & $88.89 \%$ \\
\hline \multicolumn{2}{|c|}{ Jumlah } & 36 & $100 \%$ \\
\hline
\end{tabular}

(Sumber: Dokumentasi nilai ulangan harian Kompetensi Dasar (KD) Memahami persyaratan perlakuan panas logam pada kelas X TMI 2 SMKN 1 Tunjung Teja Tahun Pelajaran 2020/2021)

Data di atas menunjukkan total 36 siswa kelas X TMI 2 SMKN 1 Tunjung Teja Tahun Pelajaran 2020/2021, sebanyak 4 siswa (11,11\%) mencapai hasil Kriteria Kelulusan Minimal (KKM), sementara itu, sebanyak 32 siswa $(88,89 \%)$ belum memenuhi Kriteria Kelulusan Minimal (KKM) 70 pada KD Memahami persyaratan perlakuan panas logam. Salah satu faktor yang diduga berpengaruh terhadap nilai yang dicapai siswa adalah media pembelajaran.

Media pembelajaran merupakan unsur yang sangat penting dalam proses pembelajaran selain metode mengajar. Kedua unsur ini saling berkaitan. Pemilihan salah satu metode mengajar tertentu akan mempengaruhi jenis media pembelajaran yang digunakan. Pemakaian media pembelajaran dalam proses pembelajaran dapat membangkitkan motivasi dan rangsangan kegiatan belajar, dan bahkan membawa pengaruh-pengaruh psikologis terhadap peserta didik. Penggunaan media pembelajaran pada tahap orientasi pembelajaran sangat membantu keefektifan proses pembelajaran, penyampaian pesan dan isi pelajaran pada saat itu. Selain membangkitkan minat siswa, media pembelajaran dapat membantu siswa meningkatkan pemahaman, dan guru dapat menyajikan data dengan padat dan menarik.

Salah satu perangkat lunak yang biasa dipakai dalam penyampaian materi pelajaran adalah Microsoft Power Point. Microsoft Power Point merupakan salah satu aplikasi milik Microsoft, disamping Microsoft Word dan Microsoft Exel yang telah di kenal banyak orang. Ketiga aplikasi ini lazim disebut Microsoft Office. Pada dasarnya, aplikasi Microsoft Power Point berfungsi untuk membantu user dalam menyajikan persentasi. Aplikasi Microsoft PowerPoint menyediakan fasilitas slide untuk menampung pokok-pokok pembicaraan yang akan disampaikan pada peserta didik. Dengan fasilitas animasi, suatu slide dapat dimodifikasi dengan menarik. Begitu juga dengan adanya fasilitas: front picture, sound dan effect dapat dipakai untuk membuat suatu slide yang bagus. Bila produk slide ini digunakan, maka para pendengar dapat ditarik perhatiannya untuk menerima apa yang kita sampaikan kepada peserta didik.

Dari uraian di atas media pembelajaaran Microsoft PowerPoint berupa program media presentasi pada komputer diharapkan dapat membantu meningkatkan pemahaman sekaligus prestasi belajar siswa pada mata pelajaran Dasar Perancangan Teknik Mesin.

\section{Studi Literatur}

Menurut Briggs (87: 1977) mengemukakan bahwa media pembelajaran adalah "sarana fisik untuk menyampaikan isi/materi pembelajaran seperti buku, film, video, slide, dan sebagainya" berpendapat 
bahwa media pembelajaran adalah sarana fisik untuk menyampaikan isi/materi pembelajaran seperti: buku, film, video dan sebagainya. Sedangkan, National Education Associaton (23: 1969) mengungkapkan bahwa "media pembelajaran adalah sarana komunikasi dalam bentuk cetak maupun pandang-dengar, termasuk teknologi perangkat keras." Kemudian Brown (63: 1973) mengungkapkan bahwa "media pembelajaran yang digunakan dalam kegiatan pembelajaran dapat mempengaruhi terhadap efektivitas pembelajaran".

Pada mulanya, media pembelajaran hanya berfungsi sebagai alat bantu guru untuk mengajar yang digunakan adalah alat bantu visual. Sekitar pertengahan abad ke-20 usaha pemanfaatan visual dilengkapi dengan digunakannya alat audio, sehingga lahirlah alat bantu audio-visual. Sejalan dengan perkembangan ilmu pengetahuan dan teknologi (IPTEK), khususnya dalam bidang pendidikan, saat ini penggunaan alat bantu atau media pembelajaran menjadi semakin luas dan interaktif, seperti adanya komputer dan internet. Dari ketiga pendapat di atas disimpulkan bahwa media pembelajaran adalah segala sesuatu yang dapat menyalurkan pesan, dapat merangsang fikiran, perasaan, dan kemauan siswa sehingga dapat mendorong terciptanya proses belajar pada diri siswa.

Dede Suratman melakukan penelitian dengan judul "Pemanfaatan Ms Power Point Dalam Pembelajaran". Hasil yang telah dicapai dalam penelitian ini adalah lebih memotivasi dan meningkatkan prestasi belajar siswa. Hal ini dikarenakan adanya penggunaan media pembelajaran Microsoft PowerPoint, yang mana memberikan pengaruh pada motivasi dan prestasi belajar siswa. Persamaan dengan penelitian yang dilakukan oleh penulis adalah media yang digunakan sama yaitu dengan menggunakan media Microsoft Powerpoint dan salah satu variabelnya sama yaitu media Microsoft Powerpoint sedangkan perbedaan dalam penelitian ini adalah adanya salah satu variabel yang berbeda di teliti. Dalam penelitian oleh Dede Suratman meneliti motivasi siswa, sedangkan penulis meneliti hasil belajar siswa dalam penggunaan media Microsoft PowerPoint. Hal lain yang berbeda adalah tempat penelitian, Dede Suratman meneliti di sekolah dan penulis meneliti di SMKN 1 Tunjung Teja Pada Mata Pelajaran Dasar Perancangan Teknik Mesin pada Siswa Kelas X TMI 2.

Penggunaan media Microsoft Powerpoint adalah upaya yang perlu ditempuh dalam rangka mencapai tujuan pembelajaran Mata Pelajaran Dasar Perancangan Teknik Mesin, dimana perlu kita ketahui bahwa dengan penggunaan media Microsoft Powerpoint maka akan berpengaruh terhadap hasil belajar siswa terhadap pelajaran Dasar Perancangan Teknik Mesin. Media Microsoft Powerpoint merupakan pembelajaran yang optimal karena bervariatif dalam menampilkan materi yang akan diajarkan. Hal ini akan mengurangi tingkat kebosanan dan kejenuhan siswa. Adapun kerangka berfikir yang akan digambarkan dalam bagan sebagai berikut:

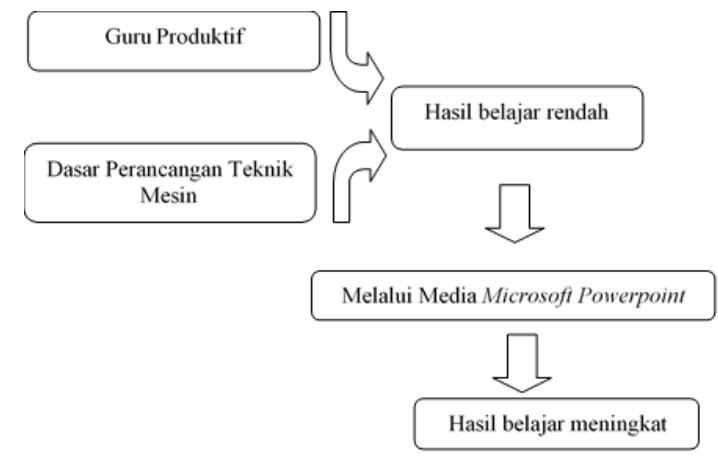

Metode Penelitian

Hasil belajar meningkat

Penelitian ini dilaksanakan di kelas X TMI 2 SMKN 1 Tunjung Teja Kabupaten Serang sebanyak 20 Siswa laki-laki. Penelitian ini adalah Penelitian Tindakan Kelas yang mengarah kepada model Kemmis 
dan MC Taggart (Arikunto, 2007:16). Penelitian tindakan kelas ini dilaksanakan dalam 3 siklus, masingmasing siklus terdiri dari empat tahap yaitu perencanaan (planning), pelaksanaan tindakan (action), pengamatan (observasi) dan refleksi.

\section{Hasil}

Sebelum melakukan tindakan dalam penelitian, peneliti melakukan data ulangan harian siswa di kelas. Hasil ulangan harian siswa menunjukkan persentase daya serap klasikal sebesar 30\% dan ketuntasan belajar klasikal sebesar 25\%. Dari 4236 siswa kelas X TMI 2 SMKN 1 Tunjung Teja Tahun Pelajaran 2020/2021, sebanyak 4 siswa (11,11\%) mencapai hasil Kriteria Kelulusan Minimal (KKM), sementara itu, sebanyak 32 siswa $(88,89 \%)$ belum memenuhi Kriteria Kelulusan Minimal (KKMg) 70 pada KD Memahami persyaratan perlakuan panas logam.

\section{Deskripsi Tindakan Siklus I, II dan III}

Penelitian tindakan kelas (PTK) ini dilakukan dengan 3 siklus, setiap siklus dilakukan 1 kali pertemuan. Setiap siklus dilakukan kegiatan yang terdiri atas: (1) Perencanaan; (2) Pelaksanaan Tindakan; (3) Observasi; (4) Refleksi. Berikut ini uraian siklusnya:

Siklus I

a. Perencanaan

Dalam perencanaan peneliti menyusun RPP, Mempersiapkan materi dan Media pembelajaran yang iteraktif. (Modul, LKPD, Media Microsoft PowerPoint dan Video Pembelajaran), Membuat dan menyiapkan lembar pengamatan, dan Membuat dan menyiapkan tes untuk evaluasi (Google Form)

b. Pelaksanaan Tindakan

Dalam kegiatan ini peneliti melakukan persiapan seperti menjelaskan tujuan pembelajaran yang ingin dicapai, guru membagi siswa dalam kelompok, guru membagikan modul dan Lembar Kerja Siswa (LKPD), guru menyediakan skenario pembelajaran yang sudah disiapkan, guru membimbing siswa dalam kegiatan tersebut, Siswa diberikan kesempatan untuk bertanya setelah informasi diberikan, setiap kelompok mempresentasikan hasil diskusi, siswa dan guru membahas hasil kegiatan kelompok, siswa dan guru membuat kesimpulan, Siswa melaksanakan evaluasi. Setelah persiapan dilanjutkan penyampaian materi setiap pertemuan dikelompokkan menjadi 3 bagian, yaitu awal pembelajaran (pendahuluan), kegiatan inti, akhir pembelajaran (penutup).

c. Pengamatan

Pengamatan dilakukan oleh observer sebagai guru sewaktu proses pembelajaran dengan menggunakan instrumen penelitian berupa lembar pengamatan aktivitas belajar siswa. Sedangkan untuk penilaian hasil belajar dilakukan menggunakan lembaran evaluasi pada akhir siklus I dengan menggunakan google form.

\section{Tabel 4.1. Hasil Observasi Aktifitas Siswa Siklus I, II dan III}

\begin{tabular}{|l|l|l|l|l|}
\hline \multirow{2}{*}{ No } & Indikator yang di amati & \multicolumn{3}{|c|}{ Hasil Penelitian } \\
\cline { 3 - 5 } & & Siklus 1 & Siklus 2 & Siklus 3 \\
\hline
\end{tabular}


Edu Cendikia: Jurnal Ilmiah Kependidikan

Volume: 1 | Nomor 3 | Desember 2021 | E-ISSN: 2798-365X | DOI: 10.47709/educendikia.v1i3.1178

\begin{tabular}{|c|c|c|c|c|}
\hline 1 & $\begin{array}{l}\text { Kesiapan siswa mengikuti kegiatan } \\
\text { pembelajaran }\end{array}$ & 2 & 3 & 3 \\
\hline 2 & Memperhatikan penjelasan guru & 3 & 4 & 4 \\
\hline 3 & $\begin{array}{l}\text { Memberi tanggapan tetang konsep } \\
\text { yang diberikan dan kaitanya dalam } \\
\text { kehidupan sehari-hari }\end{array}$ & 3 & 3 & 4 \\
\hline 4 & $\begin{array}{l}\text { Menyimak tujuan pembelajaran } \\
\text { yang disampaikan }\end{array}$ & 3 & 4 & 4 \\
\hline 5 & $\begin{array}{l}\text { Siswa memperhatikan materi } \\
\text { pelajaran yang diberikan dan } \\
\text { disampaikan oleh guru melalui } \\
\text { media Microsoft PowerPoint }\end{array}$ & 3 & 3 & 4 \\
\hline 6 & $\begin{array}{l}\text { Keaktifan siswa dalam proses } \\
\text { pembelajaran media Microsoft } \\
\text { PowerPoint }\end{array}$ & 3 & 3 & 4 \\
\hline 7 & $\begin{array}{l}\text { Mengajukan pertanyaan dan } \\
\text { memberikan komentar }\end{array}$ & 2 & 3 & 3 \\
\hline 8 & $\begin{array}{l}\text { Menyimpulkan materi yang telah } \\
\text { dipelajari }\end{array}$ & 2 & 3 & 3 \\
\hline 9 & $\begin{array}{lll}\text { Mengerjakan } & \text { evaluasi } & \text { yang } \\
\text { diberikan guru } & & \end{array}$ & 2 & 2 & 3 \\
\hline \multicolumn{2}{|c|}{ Jumlah } & 23 & 28 & 32 \\
\hline \multicolumn{2}{|r|}{ Persentase $(\%)$} & $64 \%$ & $78 \%$ & $89 \%$ \\
\hline
\end{tabular}

Tabel 4.2 Hasil Belajar Siklus I, II dan III

\begin{tabular}{|l|l|c|c|c|}
\hline \multirow{2}{*}{ No. } & \multicolumn{2}{|c|}{ Nama Siswa } & \multicolumn{3}{c|}{ Nilai yang diperoleh } \\
\cline { 3 - 5 } & & Siklus I & Siklus II & Siklus III \\
\hline 1 & Aditya & 40 & 80 & 80 \\
\hline 2 & Arya Alam Fathallah & 20 & 40 & 80 \\
\hline 3 & Baetul Rohman & 20 & 80 & 80 \\
\hline 4 & Dede Riyadi & 80 & 100 & 80 \\
\hline 5 & Egi Al Ajar & 20 & 80 & 80 \\
\hline 6 & Pazru & 20 & 60 & 80 \\
\hline 7 & M. Adi yanto & 80 & 100 & 100 \\
\hline 8 & Muhamad Afryansyah & 80 & 100 & 100 \\
\hline 9 & M. Ardiansyah & 20 & 60 & 60 \\
\hline 10 & Mahesa Anwar & 40 & 40 & 100 \\
\hline 11 & Muhamad Alpaiji & 40 & 40 & 60 \\
\hline
\end{tabular}


Edu Cendikia: Jurnal Ilmiah Kependidikan

Volume: 1 | Nomor 3 | Desember 2021 | E-ISSN: 2798-365X | DOI: 10.47709/educendikia.vli3.1178

\begin{tabular}{|c|l|c|c|c|}
\hline 12 & Muhamad Rian Sumantri & 40 & 60 & 60 \\
\hline 13 & Muhammad Arifin Ilham & 60 & 100 & 80 \\
\hline 14 & Muktar Kusuma & 80 & 100 & 80 \\
\hline 15 & Patha Kholaip & 60 & 80 & 80 \\
\hline 16 & Ridwan & 80 & 100 & 100 \\
\hline 17 & Rizky Agus Salim & 20 & 80 & 100 \\
\hline 18 & Sudrajat & 80 & 100 & 100 \\
\hline 19 & Suryadi & 40 & 80 & 80 \\
\hline 20 & Tedi Triyana & 20 & 40 & 60 \\
\hline & Rata-Rata Nilai & $\mathbf{4 7}$ & $\mathbf{7 6}$ & $\mathbf{8 2}$ \\
\hline
\end{tabular}

1) Refleksi

Setelah pengamatan dirasakan belum ada peningkatan dalam hasil belajar siswa sehingga perlu adanya rencana perbaikan pembelajaran. Refleksi ini meliputi: evaluasi tindakan mengenai hasil aktivitas dan evaluasi belajar yang dinilai melalui hasil evaluasi objektif di akhir siklus, dan memperbaiki pelaksanaan tindakan sesuai hasil evaluasi tentang indikator apa yang sudah tercapai dan belum tercapai, untuk diterapkan pada siklus II.

Siklus II

Pelaksanaan proses pembelajaran pada siklus kedua ini berdasarkan hasil refleksi pada siklus pertama dan rencana perbaikan pembelajaran yang telah disusun untuk siklus kedua. Tahapan proses pembelajaran pada siklus kedua sama seperti pembelajaran siklus pertama. Setelah proses pembelajaran, pada akhir siklus akan diberikan evaluasi dalam bentuk pilihan ganda untuk mengetahui hasil belajar (kemampuan penguasaan materi).

\section{Siklus III}

Pelaksanaan proses pembelajaran pada siklus ketiga ini berdasarkan hasil refleksi pada siklus kedua dan rencana perbaikan pembelajaran yang telah disusun untuk siklus ketiga. Tahapan proses pembelajaran pada siklus ketiga sama seperti pembelajaran siklus kedua. Setelah proses pembelajaran, pada akhir siklus akan diberikan evaluasi dalam bentuk pilihan ganda untuk mengetahui hasil belajar (kemampuan penguasaan materi).

Tabel 4.4 Hasil Analisis Evaluasi Siklus I, II dan III

\begin{tabular}{|l|l|c|c|c|}
\hline \multirow{2}{*}{ No. } & \multicolumn{1}{|c|}{ Aspek Perolehan } & \multicolumn{3}{|c|}{ Hasil yang diperoleh } \\
\cline { 3 - 5 } & & Siklus I & Siklus II & Siklus III \\
\hline 1 & Skor Tertinggi & 80 & 100 & 100 \\
\hline 2 & Skor Terendah & 20 & 40 & 60 \\
\hline 3 & Banyak Siswa yang tuntas & 6 orang & 13 orang & 16 orang \\
\hline
\end{tabular}


Edu Cendikia: Jurnal Ilmiah Kependidikan

Volume: 1 | Nomor 3 | Desember 2021 | E-ISSN: 2798-365X | DOI: 10.47709/educendikia.v1i3.1178

\begin{tabular}{|c|c|c|c|c|}
\hline 4 & Banyak Siswa yang tidak tuntas & $\begin{array}{c}14 \\
\text { orang }\end{array}$ & 7 orang & 4 orang \\
\hline 5 & Presentasi Daya Serap Klasikal & $47 \%$ & $76 \%$ & $82 \%$ \\
\hline 6 & $\begin{array}{lll}\text { Presentasi } & \text { Ketuntasan } & \text { Belajar } \\
\text { Klasikal } & & \\
\end{array}$ & $30 \%$ & $65 \%$ & $80 \%$ \\
\hline
\end{tabular}

\section{Pembahasan}

Berdasarkan penelitian yang dilakukan, dari hasil evaluasi siswa siklus I terdapat 6 orang siswa yang tuntas belajar dan 14 orang siswa yang tidak tuntas belajar, dengan nilai tertinggi sebesar 80 dan nilai terendah 20 dari nilai maksimal 100. Persentase ketuntasan belajar klasikal $30 \%$ dan daya serap klasikal 47\%. Berdasarkan dari hasil ketuntasan belajar klasikal siswa siklus I, dapat diketahui bahwa belum begitu baik.

Hasil penelitian siklus I terhadap lembar observasi aktifitas siswa pada proses pembelajaran diperoleh nilai persentase aktifitas siswa $64 \%$ yang masuk dalam kategori cukup baik, namun masih terdapat kekurangan dalam pelaksanaannya disebabkan karena siswa kurang memperhatikan/menyimak penjelasan guru, siswa masih merasa malu untuk memberikan tanggapan, kesimpulan dan menjawab pertanyaan yang diberikan guru. Hal ini terlihat pada lembar aktifitas siswa dalam kegiatan belajar mengajar (lihat tabel 4.1).

Adanya kekurangan-kekurangan tersebut maka perlu dilakukan tindakan berupa perbaikan pada siklus II yaitu: Guru lebih memberikan bimbingan pada siswa agar lebih memperhatikan penjelasan guru, Guru memberikan motivasi kepada siswa agar lebih percaya diri, lebih berani, dan mampu dalam mengajukan dan menjawab pertanyaan, Guru lebih membimbing siswa dalam menyimpulkan materi, dan Guru lebih menanamkan rasa percaya diri pada siswa.

Melihat hasil siklus I yang belum tuntas maka hal ini mendorong peneliti untuk melakukan refleksi dan hal-hal apa yang perlu dilakukan untuk memperbaiki pelaksanaan tindakan pada siklus II antara lain guru lebih memotivasi siswa dan memberi penguatan sehingga siswa lebih mampu dalam menjawab pertanyaan yang diajukan guru. Menghubungkan kegiatan pembelajaran dengan kehidupan sehari-hari dan memotivasi siswa, sangat diperlukan dalam kegiatan pembelajaran. Gagne dan Bliner dalam Dahar (1989:53) menyatakan bahwa dalam kegiatan pembelajaran, perhatian dan motivasi mempunyai peranan penting dalam kegiatan belajar. Motivasi dan perhatian merupakan tenaga penggerak aktifitas belajar siswa.

Pada siklus II dari hasil evaluasi siswa terdapat 13 orang siswa yang tuntas belajar dan 7 orang siswa yang tidak tuntas belajar dengan nilai tertinggi sebesar 100 dan nilai terendah 40 dari skor maksimal 100. Persentase ketuntasan belajar klasikal 65\% dan daya serap klasikal 76\%. Berdasarkan hasil observasi aktifitas siswa di siklus II diperoleh nilai persentase siswa $78 \%$ yang termasuk dalam kategori baik, dengan melihat kriteria taraf keberhasilan tindakan. Dengan adanya peningkatan pada siklus II, maka dapat dilihat hampir semua siswa sudah memperhatikan penjelasan guru sehingga siswa sudah mulai berani dan tidak malu lagi untuk mengemukakan pendapatnya mengenai materi pelajaran. Melalui hasil evaluasi tersebut dapat diketahui adanya peningkatan pada siklus II, namun masih ada siswa yang belum tuntas dalam perolehan nilai. 
Adanya kekurangan-kekurangan tersebut maka perlu dilakukan tindakan berupa perbaikan pada siklus III yaitu: Guru lebih memberikan perhatian khusus pada siswa masih rendah nilainya agar lebih fokus dan paham penjelasan guru, dan Guru selalu memberikan motivasi kepada siswa agar lebih percaya diri, lebih berani, dan mampu dalam mengajukan dan menjawab pertanyaan.

Melihat hasil siklus II yang belum tuntas maka hal ini mendorong peneliti untuk melakukan refleksi dan hal-hal apa yang perlu dilakukan untuk memperbaiki pelaksanaan tindakan pada siklus III antara lain guru memberi stimulus pada media powerpoint untuk lebih memotivasi siswa dan memberi penguatan sehingga siswa lebih mampu dalam menjawab pertanyaan yang diajukan guru. Menghubungkan kegiatan pembelajaran dengan kehidupan sehari-hari dan memotivasi siswa, sangat diperlukan dalam kegiatan pembelajaran.

Pada siklus III dari hasil evaluasi siswa terdapat 16 orang siswa yang tuntas belajar dan 4 orang siswa yang tidak tuntas belajar dengan nilai tertinggi sebesar 100 dan nilai terendah 60 dari skor maksimal 100. Persentase ketuntasan belajar klasikal $80 \%$ dan daya serap klasikal 82\%. Melalui hasil evaluasi tersebut dapat diketahui adanya peningkatan pada siklus III mejadi lebih baik, walaupun masih ada sedikit siswa yang belum tuntas dalam perolehan nilai. Hal ini disebabkan karena tingkat pemahaman siswa tersebut masih rendah sehingga mengalami keterlambatan menerima materi pelajaran.

Berdasarkan informasi dari guru mata pelajaran lain bahwa empat orang siswa yang tidak tuntas ini seringkali tidak mengikuti kegiatan belajar mengajar dan minat belajarnya kurang. Untuk mengantisipasi hal tersebut, siswa diberikan bimbingan dan perhatian khusus yang bersifat membangun dalam proses belajar mengajar.

Berdasarkan hasil observasi aktifitas guru dan siswa di siklus III diperoleh nilai persentase kegiatan guru 90\% dan siswa 89\% yang termasuk dalam kategori sangat baik, dengan melihat kriteria taraf keberhasilan tindakan. Dengan adanya peningkatan pada siklus III, maka dapat dilihat hampir semua siswa sudah memperhatikan penjelasan guru sehingga siswa sudah mulai berani dan tidak malu lagi untuk mengemukakan pendapatnya mengenai materi pelajaran, siswa sudah serius dan aktif dalam kegiatan pembelajaran dengan mengunakan media Microsoft Pawer Point, siswa sudah mampu menyimpulkan materi yang diajarkan sesuai dengan tujuan pembelajaran karena sudah memahami konsep-konsep materi yang diajarkan dan siswa sudah memiliki rasa percaya diri sehingga sudah berani dan aktif mengungkapkan jawaban maupun menanggapi pertanyaan baik kepada guru maupun kepada temannya. Peningkatan aktifitas siswa ini disebabkan karena kegiatan guru yang semakin baik dalam proses pembelajaran, seperti guru terus berusaha memberikan motivasi dan bimbingan kepada siswa agar siswa berminat dan aktif dalam mengikuti proses belajar mengajar.

Berdasarkan hasil tersebut, dapat dijelaskan bahwa penggunaan media Microsoft Pawer Point dalam proses pembelajaran, merupakan cara mengoptimalkan pembelajaran Dasar Perancangan Teknik Mesin yang dapat meningkatkan hasil belajar Dasar Perancangan Teknik Mesin sesuai dengan penelitian yang telah dilakukan. Dari hasil analisis siklus I, siklus II dan siklus III serta hasil observasi berbagai aktivitas yang dilakukan pengamat menunjukkan bahwa implementasi penggunaan media pembelajaran yang diterapkan cukup efektif, karena pembelajaran ini dapat membuat siswa serius dan aktif dalam kegiatan belajar mengajar sehingga hasil siklus II dan siklus III selalu meningkat. Dengan demikian penggunaan media Microsoft PawerPoint dapat dijadikan salah satu alternatif dalam proses kegiatan belajar mengajar untuk meningkatkan hasil belajar siswa pada mata pelajaran Dasar Perancangan Teknik Mesin di Kelas X TMI 2 SMKN 1 Tunjung Teja. 


\section{Kesimpulan}

Berdasarkan tujuan penelitian dan hasil analisis data yang diperoleh selama pelaksanaan tindakan siklus I, II dan III dapat disimpulkan sebagai berikut:

1. Hasil belajar siswa pada siklus I diperoleh tuntas individu 6 orang dari 20 orang siswa dengan persentase daya serap klasikal sebesar $47 \%$ dan ketuntasan belajar klasikal $30 \%$. Kemudian meningkat pada siklus II diperoleh tuntas individu 13 orang dari 20 orang siswa dengan persentase daya serap klasikal sebesar $76 \%$ dan ketuntasan belajar klasikal sebesar $65 \%$. Pada akhir siklus III lebih meningkat lagi sehingga diperoleh tuntas individu 16 orang dari 20 orang siswa dengan persentase daya serap klasikal sebesar $82 \%$ dan ketuntasan belajar klasikal sebesar $80 \%$.

2. Microsoft Powerpoint mampu meningkatkan daya serap klasikal

3. MS Powerpoint mampu meningkatkan ketuntasan belajar kalsikal

\section{Ucapan Terima Kasih}

Segala puji syukur peneliti panjatkan ke hadirat Tuhan Yang Maha Esa atas berkat dan rahmat-Nya yang telah memberikan kesehatan dan kemudahan sehingga penulis dapat menyelesaikan penyusunan penelitian ini yang berjudul "Meningkatkan Hasil Belajar Siswa Melalui Media Microsoft PowerPoint Di Smkn 1 Tunjung Teja - Kabupaten Serang”. Penulis dengan segala kerendahan hati, dalam kesempatan ini penulis ingin mengucapkan terima kasih kepada Bapak/Ibu Guru SMK Negeri 1 Tunjung Teja yang telah memberikan kemudahan, masukan, bimbingan, dan arahan, sehingga penelitian ini dapat terlaksana dengan baik .

\section{Referensi}

Daryanto. 2013. Media Pembelajaran (Peranannya sangat penting dalam mencapai tujuan pembelajaran. Yogyakarta: Gava Media

Hitipeuew Arsyad, A. 2013. Media Pembelajaran. Jakarta: PT Raja Grafindo Persada

Dimyati \& Mudjiono. 2006. Belajar dan Pembelajaran. Jakarta: Rineka Cipta

Gumawan, a. 2006. Belajar Otodidak word, EXCEL, Powerpoind XP. Bandung: Informatika.

Harjanto, 1997, Metode pemmbelajaran, Jakarta. Rineka Cipta

Ibrahim, R dan Nana Syaodih S. 2003, Strategi Pembelajaran. Jakarta, Rineka Cipta

Kasbolah, K. 1998. PenelitianTindakan Kelas (PTK). Jakarta: Depdikbud.

Komputer, Wahana. 2011. Panduan Praktis Microsoft PowerPoint 2010.

Kustawan, Dedy. 2013. Analisis Hasil Belajar. Jakarta: Luxima Metro Media

Kusumaryo, Suyato. 2016. Menatap Penelitian Tindakan Kelas. Garut: Tidak Diterbitkan

Oemar Hamalik. 2001, Proses Belajar Mengajar, Jakarta. Bumi Aksara

Purwanto.2011. Evaluasi Hasil Belajar, Yokyakarta: Pustaka Belajar 
Edu Cendikia: Jurnal Ilmiah Kependidikan

Volume: 1 | Nomor 3 | Desember 2021 | E-ISSN: 2798-365X | DOI: 10.47709/educendikia.v1i3.1178

Slameto. 2010. Belajar dan Faktor yang Mempengaruhinya. Jakarta: Rineka Cipta.

Sudjana, Nana. 2016. Penilaian Hasil Proses Belajar Mengajar. Bandung: Remaja Rosdakarya

Sugiyono. 2016. Metode Penelitian Pendidikan. Bandung: Alfabeta

Sumber: Contoh Makalah Microsoft Power Point https://azzahra-official.com/?p=567 